\title{
An Analysis Of Factors Impacting The Value-Relevance Of SFAS No. 107 Fair Value Disclosures
}

Daniel R. Brickner, (E-mail: daniel.brickner@emich.edu), Eastern Michigan University

\begin{abstract}
This study examines the impact of hypothesized factors on the value-relevance of SFAS No. 107 fair value disclosures. These factors include firm size, the relative magnitude of the difference between the fair value and the historical cost measurements for each financial instrument, firm financial condition, and the quality of a firm's financial statement audit. A pooled valuation model is employed on the sample of 867 firm years for banks and bank holding companies during the period of 1996 and 1997.
\end{abstract}

The results indicate that the SFAS No. 107 fair value disclosures for investment securities, net loans, and long-term debt are value-relevant in explaining the market value of common equity for the sample banks. With respect to the hypothesized factors, firm size was found to have a statistically significant impact on the value-relevance of the disclosures for net loans and long-term debt. Additionally, the relative magnitude of the difference between the fair value and historical cost had a statistically significant effect on the value-relevance of the disclosure for investment securities and long-term debt. Finally, firm financial condition and the quality of a firm's audit were found to have a statistically significant impact on the fair value disclosure for net loans.

The results of this study are descriptive of the behavior of financial statement users with respect to these fair value disclosures. The implications of this study's findings are useful for both accounting standard-setters and preparers of financial statements. Taken together, these findings suggest that the market does not respond to the SFAS No. 107 fair value disclosures at their face value alone or without considering their context. Specifically, it appears to look to other factors that may impact the relevance and/or reliability of these disclosures.

\section{Introduction}

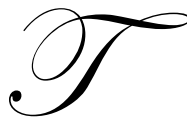

his study examines factors that impact the value-relevance of the fair value disclosures prescribed by Statement of Financial Accounting Standards No. 107 (SFAS No. 107). The Financial Accounting

Standards Board (FASB) has stated its intention to require all financial instruments be measured at fair value on the statement of financial position. They have gradually moved toward fair value recognition by issuing accounting standards requiring recognition or disclosure of fair values for certain financial instruments. SFAS No. 107 is one of the standards that increased disclosure of fair values, as it requires all entities to disclose the fair values of certain financial instruments either in the body of the financial statements or in the accompanying notes to those statements (FASB, 1991, para. 10).

Previous studies by Nelson (1996), Barth et al., (1996), and Eccher et al., (1996), examined the valuerelevance of SFAS No. 107 fair value disclosures for banks and bank holding and Simko (1999) examined the value-

Readers with comments or questions are encouraged to contact the author via email. 


\section{Journal Of Business And Economics Research}

\section{Volume 1, Number 4}

relevance of SFAS No. 107 fair value disclosures for nonfinancial firms. Taken together, these studies found SFAS No. 107 fair value disclosures provide information incremental to recognized book values.

The primary purpose of this study is to examine the impact of identified factors on the value-relevance of the SFAS No. 107 fair value disclosures. These factors include firm size, the relative magnitude of the difference between the fair value and the historical cost measurements for each financial instrument, firm financial condition, and the quality of each firm's audit.

An additional contribution of this research is the examination of the value-relevance of SFAS No. 107 disclosures after controlling for the required disclosures for derivative financial instruments, as prescribed by SFAS No. 119. 1 This research provides a further contribution as it supplements the findings of prior SFAS No. 107 studies. The findings of this study, covering a different sample and time period than previous studies, can be assimilated with the results of prior research in order to form more generalizable conclusions about the value-relevance of SFAS No. 107 disclosures.

This study employs a pooled valuation model in examining the factors that impact the value-relevance of SFAS No. 107 fair value disclosures. The sample for this study consists of 867 banks and bank holding companies during the period of 1996 and 1997. The banking industry was chosen for analysis due to the relative significance of financial instruments for such institutions.

The results of this research indicate that firm size, the relative magnitude of the difference between the fair value and historical cost of the financial instrument, firm financial condition, and the quality of a firm's audit had a statistically significant impact on the value-relevance of the SFAS No. 107 fair value disclosures. The findings suggest that market participants do not respond to these disclosures at face value, but rather look to other factors in order to evaluate the relevance and/or reliability of these disclosures.

The findings from this study should be informative to accounting standard-setters and to financial reporting users and preparers in understanding what factors affect the usefulness of these fair value disclosures. This is particularly important in light of the current movement toward fair value accounting.

The remainder of this paper is organized as follows. Section two reviews the literature related to fair value disclosures required by SFAS No. 107. Section three develops the factors hypothesized to impact the valuerelevance of the SFAS No. 107 fair value disclosures. Section four describes the research design. Section five describes the sample selection and data collection. Section six presents the results. Section seven provides a summary and concludes this study.

\section{SFAS No. 107 Research And Related Research}

\subsection{SFAS No. 107 Studies}

Four recent studies have examined the value-relevance of fair value disclosures related to SFAS No. 107 . Three of the studies used the banking industry to comprise their sample due to the significance of financial instruments on the statement of financial position for banks as well as the impact that financial instruments have on the results of their operations. These papers all focused on the major on- and off-balance sheet financial instruments.

Nelson's (1996) study examined SFAS No. 107 fair value disclosures for 146 and 133 banks for 1992 and 1993, respectively. Her results indicated that only the fair value disclosure for investment securities provided infor-

\footnotetext{
1 This standard was effective for fiscal years ending after December 15, 1994 (FASB, 1994). Prior to SFAS No. 119, the disclosures for derivative financial instruments required by SFAS No. 107 were less divulging. The three previous studies that examined SFAS No. 107 disclosures for banks, which typically have a higher concentration of derivative financial instruments than most other industries, examined the period of 1992 and 1993, which was prior to the enactment of SFAS No. 119. It is therefore not surprising that Nelson (1996) and Barth et al. (1996) found the disclosures for derivative financial instruments required by SFAS No. 107 were not value-relevant while Eccher et al. (1996) only found them to be value-relevant in limited settings.
} 


\section{Journal Of Business And Economics Research}

\section{Volume 1, Number 4}

mation incremental to recognized book values, and this finding was only for her 1992 analysis.

After controlling for firm-specific growth proxies in her model, Nelson (1996) found the fair value disclosures related to investment securities were no longer significant in either year examined. However, proxies for future growth opportunities were significant in explaining firm value for both years.

Barth et al. (1996) examined the value-relevance of SFAS No. 107 disclosures for a sample of 136 banks during the period of 1992 and 1993 . Their primary estimating equation included two other sets of variables in addition to the variables related to the SFAS No. 107 disclosures. The first set included variables that controlled for the fair value measures of other assets and liabilities that are not covered under SFAS No. 107 (i.e., nonfinancial assets and liabilities). The second set of variables controlled for competitor sources of information other than SFAS No. 107 disclosures. The primary findings from their analysis indicated that of the SFAS No. 107 financial instruments, investment securities, loans, and long-term debt were all statistically significant in explaining the difference between the market and book values of equity.

Eccher et al. (1996) examined the value-relevance of SFAS No. 107 disclosures of 296 and 328 banks for 1992 and 1993, respectively. Their results indicated that fair value estimates for securities, net loans, long-term debt and off-balance sheet financial instruments were incrementally informative in explaining the market-to-book ratio. Additionally, after controlling for several historical cost-based financial signals, Eccher et al. (1996) concluded that the SFAS No. 107 disclosures resulted in financial reporting that provides a more comprehensive source of information in financial statements when simply compared to historical cost-based measures for assets and liabilities.

Simko (1999) examined the value-relevance of SFAS No. 107 disclosures for approximately 260 nonfinancial institutions for the period of 1992-1995. He found the fair value disclosures for liabilities, which primarily consisted of long-term debt, were statistically significant in explaining firm market values for two of the years of his analysis.

\subsection{SFAS No. 119 Study}

Venkatachalam (1996) examined 99 bank holding companies as of the end of 1994 to determine if the fair value disclosures for banks' derivative financial instruments required by SFAS No. 119 explained cross-sectional differences in bank share prices. In contrast to the general findings related to derivative disclosures in the three SFAS No. 107 bank studies, Venkatachalam (1996) found that the fair value disclosures related to derivatives used for asset-liability management purposes were value-relevant in explaining the market value of firm equity. The primary contribution of this research was the conclusion that the derivative disclosures provided under SFAS No. 119 were superior to those provided in SFAS No. 107 as examined by Nelson (1996), Barth et al. (1996), and Eccher et al. (1996).

In summary, previous research has examined the value-relevance of SFAS No. 107 fair value disclosures for both financial and nonfinancial firms. This paper contributes to the research by examining the factors that impact the value-relevance of SFAS No. 107 fair value disclosures.

\section{Development Of Hypothesized Factors}

The factors hypothesized to impact the relevance and/or reliability of SFAS No. 107 fair value disclosures are described below.

\subsection{Size}

The primary reason the FASB has permitted postponement of the initial adoption of some of its standards is to allow entities adequate time to prepare for the additional reporting requirements required by the respective standards. With respect to SFAS No. 107, in which smaller entities had the option to postpone adoption (FASB, 1991, 


\section{Journal Of Business And Economics Research}

\section{Volume 1, Number 4}

para. 16), it seems reasonable to presume that the FASB believed that larger entities may have had the necessary systems in place to develop more accurate estimates of fair value. If this presumption is valid, it would appear that larger firms would be able to provide more reliable, value-relevant fair value estimates related to the SFAS No. 107 disclosures.

In contrast, one could theorize that the fair value disclosures of smaller banks might be more relevant to the market than disclosures of larger banks. Petroni and Wahlen (1995) noted that it can be argued that larger banks are more likely to invest in assets that are less frequently traded. This could make it more difficult to develop an accurate fair value estimate for these assets. Additionally, it could present these banks with an informational advantage. Both of these factors could reduce the reliability, and therefore value-relevance, of the SFAS No. 107 fair value estimates for larger banks. ${ }^{2}$

Finally, an intuitive argument can be presented that differences in the market following between relatively large and small firms could impact the value-relevance of their fair value disclosures. Specifically, since smaller firms would likely have a smaller market following, less information would tend to be demanded from these firms, and therefore, less information about these firms would be publicly available. Therefore, the relative lack of information available for smaller firms could increase the value-relevance of their SFAS No. 107 disclosures. On the contrary, one could argue that the smaller market following for smaller firms leads to a less-pronounced reaction to their fair value disclosures.

A proxy for size, total assets, is included in the model as a dichotomous variable which interacts with the SFAS No. 107 variables. $^{3}$ Due to the differing arguments related to the impact of firm size on the relevance and reliability of the SFAS No. 107 disclosures, no predictions are made about the expected sign for the size interaction variables included in the model.

\subsection{Relative Magnitude Of The Difference Between The Fair Value And Historical Cost}

SFAC No. 2 states conceptually that accounting standards should result in the provision of more useful and relevant information to financial statement users (FASB, 1980). It follows then that the FASB believes that the fair value disclosures required by SFAS No. 107 provide incremental information beyond historical cost measures.

Instances will occur where the fair value estimates for certain financial instruments of some companies closely approximate historical cost. One could argue that upon such an occurrence, the amount of incremental information provided by the fair value disclosures is relatively small. Likewise, it can be argued that larger differences between fair value and historical cost measurements would result in a greater market response, thereby increasing the value-relevance of these disclosures.

This factor is incorporated in the model by creating a standardized measure for each financial instrument examined, as shown below, for financial instrument $v$, firm $i$, at time $t^{4}$.

\footnotetext{
2 Eccher et al. (1996) noted these issues in their study. They controlled for firm size in their model by partitioning their full sample into two subsamples based on total assets. They found differences in the value-relevance of individual financial instruments between the two subsamples, providing evidence that firm size does influence the value-relevance of these disclosures.

3 Specifically, the size proxy is coded ' 1 ' if the sample firm's total assets is below the sample median and ' 0 ' otherwise.

4 If the denominator for this ratio is zero, then the standardized measure is recorded as zero.
} 


\section{Journal Of Business And Economics Research}

\section{Volume 1, Number 4}

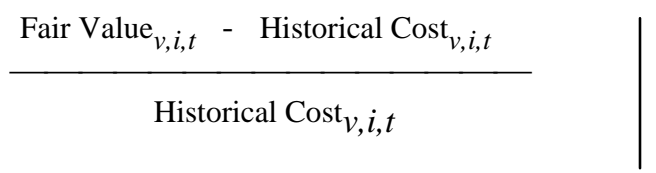

If market participants perceive relatively large differences between the fair value estimates and historical cost measures as enhancing the relevance of the disclosure, then the sign of this factor for each financial instrument is expected to be the same as the predicted sign of each financial instrument variable included in the model (i.e., positive signs for assets and negative signs for liabilities, as described below). However, if market participants view relatively large differences between fair values and historical cost the result of an unrealistic or inaccurate estimate for the fair value disclosures, then the sign of this factor is expected to be the opposite of the predicted sign for each financial instrument variable included in the model.

\subsection{Financial Condition}

Another factor hypothesized to impact the value-relevance of the SFAS No. 107 disclosures is the financial condition of the entity. Barth et al. (1996) notes that the subjective nature of the fair value estimates for the loan variable exposes them to management manipulation. It follows that firms experiencing financial difficulty would have a higher incentive to conceal their financial condition by manipulating their fair value disclosures. An efficient market should be aware of the possibility of such opportunistic behavior, and therefore might discount the fair value disclosures of less-healthy entities.

A proxy for financial condition, the total capital ratio, is included in the model as a dichotomous variable which interacts with the fair value disclosure for net loans. ${ }^{5}$ It is contended that the financial condition of a bank influences the reliability of the fair value disclosures for loans. Therefore, financial condition is predicted to be positively related to the value-relevance of the fair value disclosures for net loans.

\subsection{Audit Quality}

The disclosures related to SFAS No. 107 are required to be audited (for entities which are required or choose to be audited). Thus, the quality of the audit may be a factor in the reliability of the SFAS No. 107 disclosures. The auditor's responsibility includes obtaining sufficient competent evidential matter to reasonably assure that "the valuation principles are acceptable, are being consistently applied, and are supported by the underlying documentation and the method of estimation and significant assumptions used are properly disclosed (American Institute of Certified Public Accountants, 1992, para. 2).

DeAngelo (1981) constructed a theoretical framework from which she argued that audit quality was not independent of the size of the auditing firm. Specifically, she argued that incumbent auditing firms earn client-specific quasi-rents. Therefore, a large auditing firm that has a sizable client-base has a greater risk of losing more of these quasi-rents if they fail to report a client's material departure from generally accepted accounting standards. Based on this theory, it follows that larger auditing firms provide a higher quality audit.

A proxy for audit quality, the size of the sample firm's auditor, is included in the model as a dichotomous variable which interacts with the fair value disclosure for net loans. ${ }^{6}$ It is hypothesized that a lower quality audit di-

\footnotetext{
5 Specifically, the financial condition proxy is coded ' 1 ' if the sample firm's total capital ratio is below the sample median and ' 0 ' otherwise. This methodology was also employed by Barth et al. (1996).

6 Specifically, audit quality is coded ' 1 ' if the sample firm's auditor was not a Big-Six auditor and ' 0 ' otherwise. Subsequent to the sample period of 1996 and 1997, two of the Big-Six auditing firms, Coopers \& Lybrand and Price Waterhouse, merged, resulting in the Big-Five auditing firms.
} 


\section{Journal Of Business And Economics Research}

\section{Volume 1, Number 4}

minishes the reliability of the SFAS No. 107 disclosure for net loans, leading to the prediction that audit quality is positively related to the value-relevance of the fair value disclosures for net loans.

\section{Research Design}

Previous research by Nelson (1996), Barth et al. (1996), and Eccher et al. (1996) employed some variation of a market valuation model in examining the value-relevance of SFAS No. 107 disclosures. ${ }^{7}$ Their framework is followed in developing a model to empirically test the impact of the hypothesize factors on the value-relevance of SFAS No. 107 fair value disclosures. The first step in this development is to begin with the following accounting identity, stated in terms of market values.

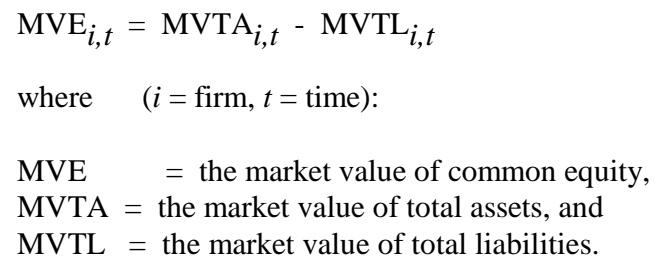

This identity holds when asset synergies, unrecognized intangible assets and other off-balance sheet assets or liabilities are absent. ${ }^{8}$ By incorporating historical cost measures, equation (2) can be restated as follows. ${ }^{9}$



where previously defined variables are as before:

HC_TA $=$ the historical cost of total assets,

HC_TL $=$ the historical cost of total liabilities,

DIF_TA $=$ the difference between the fair value and historical cost of total assets, and

DIF_TL $=$ the difference between the fair value and historical cost of total liabilities.

Equation (3) can be further specified by incorporating individual asset and liability measures and controlling for other variables which prior research has shown could impact the market value of sample banks. On the balance sheet for most banks, investment securities and loans comprise the most significant proportion of assets, while deposits and long-term debt represent their most significant liabilities. ${ }^{10}$ Equation (3) can be expanded and operationalized for empirical testing as the following statistical model.

\footnotetext{
7 Value-relevance is defined here as the ability of the disclosure to explain the market value of firm equity.

8 Under such conditions, the explanatory power of a regression for this identity should be equal to one. However, since the above conditions are unlikely in a practical setting, I will attempt to control for unrecognized assets and liabilities in my statistical model. Additionally, as noted in Barth et al. (1996), this identity would only hold in the presence of perfect and complete markets for each asset and liability (i.e., the absence of private information). The absence of this condition could be a source of coefficient bias in the statistical model.

9 Equation (2) is defined in terms of market values, while equation (3) employs the term fair value for the definition of DIF_TA and DIF_TL. The terms market value and fair value are often used interchangeably. Fair values will be used hereafter since SFAS No. 107 requires the disclosure of fair values.

10 Each of these assets and liabilities are financial instruments for which fair value disclosures are required according to the provisions of SFAS No. 107.
} 
Journal Of Business And Economics Research

Volume 1, Number 4

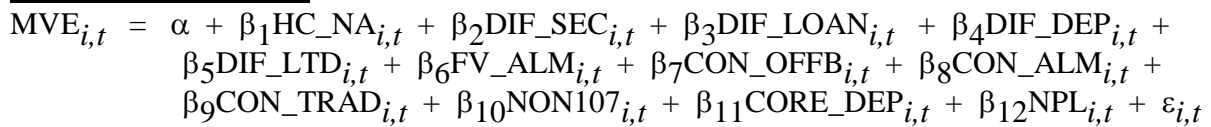

where previously defined variables are as before and $\alpha$ is the model intercept and $\varepsilon$ is the model error term:

$\begin{array}{ll}\text { HC_NA } & \text { the difference between the historical cost of total assets and total liabilities (i.e., net assets), }{ }^{11} \\ \text { DIF_SEC } & \text { the difference between the fair value and the historical cost of investment securities, }{ }^{12} \\ \text { DIF_LOAN } & \text { the difference between the fair value and historical cost of net loans, } \\ \text { DIF_DEP } & =\text { the difference between the fair value and historical cost of deposits, } \\ \text { DIF_LTD } & \text { the difference between the fair value and historical cost of long-term debt, } \\ = & \text { the fair value of derivative financial instruments used for asset-liability management purposes } \\ \text { FV_ALM } & \text { (primarily to hedge against risks associated with on-balance sheet assets and liabilities), }{ }^{13} \\ \text { CON_OFFB }= & \text { the contractual amount of credit-related off-balance sheet financial instruments, } 14 \\ \text { CON_ALM } & =\text { the contractual (notional) amount of derivatives used for asset-liability management purposes, } \\ \text { CON_TRAD }= & \text { the contractual (notional) amount of derivatives used for trading, } \\ \text { NON107 } & =\text { the historical cost of net assets other than the recognized SFAS No. } 107 \text { financial instruments } \\ & \text { accounted for separately in the model, } \\ \text { CORE_DEP }= & \text { a proxy for the core deposit intangible, measured as total domestic deposits less total time } \\ & \text { deposits, } \\ = & \text { non-performing loans, measured as the sum of loans placed on non-accrual status, loans ninety } \\ \text { NPL } & \text { days or more past due and still accruing interest, and restructured loans. }\end{array}$

In interpreting the results from a regression of model (4), the coefficient for each SFAS No. 107 variable would be positive (negative) and significant if the fair value disclosure provides information beyond historical cost measures for that SFAS No. 107 asset (liability). ${ }^{15}$

Since many banks hold significant off-balance sheet financial instruments, FV_ALM, CON_OFFB, CON_ALM, and CON_TRAD are included as control variables in the model. FV_ALM is predicted to be positively related to the market value of firm equity, whereas no signs are predicted for CON_OFFB, CON_ALM, and CON_TRAD. 16

\footnotetext{
11 Historical cost measures are the primary basis for preparing financial statements. However, there are instances when amounts recognized on the balance sheet are different from the initial cost of a transaction. An example of this is the write-down of an asset due to impairment. For expositional purposes, historical cost is used here to refer to amounts recognized on the balance sheet, with the exception of available-for-sale securities. In accordance with SFAS No. 115, these securities are recognized on the balance sheet at their fair value. Therefore, in measuring HC_NA, the historical cost of available-for-sale securities is used.

12 DIF_SEC accounts for securities classified as either available-for-sale or held-to-maturity, which are two of the three classifications required under SFAS No. 115. If an entity classifies securities as trading securities, which is the third classification prescribed under SFAS No. 115, those securities are to be recognized on the balance sheet at their fair value and the changes in their fair value from one period to the next are included in the income statement. The historical cost of trading securities is not a required disclosure under SFAS No. 115. Additionally, trading account assets and liabilities, including trading securities, were relatively insignificant across the sample firms in this study, and therefore were not separately accounted for in either of the models examined, but rather were accounted for in the variable NON107 which is described below.

13 SFAS No. 119 amends SFAS No. 107 by requiring companies to clearly indicate whether the fair value represents an asset (i.e., an unrealized gain) or a liability (i.e., an unrealized loss). Also, the standard prohibits the netting of the fair value of more than one derivative financial instrument (FASB, 1994). Consistent with prior research and in order to make the model more succinct, the fair values of all of these items are aggregated for the purpose of formulating the net position of these instruments. In cases where the netting results in an unrealized loss, the variable is recorded as a negative number.

14 These instruments primarily consist of commitments to extend credit and standby letters of credit. Commitments to extend credit provide an additional financing source to a bank's customers; while standby letters of credit improve the credit worthiness of a bank's customers.

15 The expectation of negative coefficients for the liability variables results from the structure of model (5) where all independent variables are added together in explaining the dependent variable, market value of equity. All of the data for liability measures have been entered as positive amounts.

16 CON_OFFB is expected to be positively related to the market value of firm equity only if the expected fee income received from customers exercising these instruments exceeds the expected credit risk related to issuing these instruments. CON_ALM is expected to be positive if the market rewards sample firms for hedging their risk; although, empirical research has shown a negative sign for this measure [See (Venkatacha-
} 


\section{Journal Of Business And Economics Research}

\section{Volume 1, Number 4}

NON107 denotes the recognized historical cost of net assets other than the recognized SFAS No. 107 financial instruments which are separately accounted for in the model. This variable is included in the model to control for the potential aggregate difference between the fair value and historical cost of these net assets. ${ }^{17}$ Consistent with prior research, no prediction is made about the expected sign of this variable.

CORE_DEP represents a proxy for the core deposit intangible. ${ }^{18,19}$ This variable is expected to be positively related to the market value of firm equity. NPL represents total non-performing loans disclosed by sample banks. Prior research has shown this variable to be significant in explaining firm value for banks, even after controlling for the fair value of net loans [See Barth et al. (1996) and Venkatachalam (1996)]. NPL is expected to be negatively associated with the market value of firm equity.

Since the primary purpose of this analysis is to examine the impact of the hypothesized factors on the valuerelevance of the fair value disclosures for each SFAS No. 107 financial instrument, model (4) can be expanded as shown below.

$$
\begin{aligned}
& \mathrm{MVE}_{i, t}=\alpha+\beta_{1} \mathrm{HC}_{-} \mathrm{NA}_{i, t}+\beta_{2} \mathrm{DIF}_{-} \mathrm{SEC}_{i, t}+\beta_{3} \mathrm{DIF}_{-} \mathrm{LOAN}_{i, t}+\beta_{4} \mathrm{DIF}_{-} \mathrm{DEP}_{i, t}+
\end{aligned}
$$

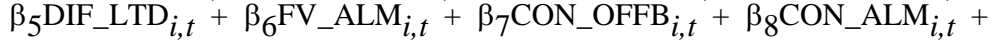

$$
\begin{aligned}
& \beta_{9} \text { CON_TRAD } i, t+\beta_{10} \text { NON107 }_{i, t}+\beta_{11} \text { CORE_DEP }_{i, t}+\beta_{12} \mathrm{NPL}_{i, t}+ \\
& \beta_{13} \text { SEC_SIZE }_{i, t}+\beta_{14} \mathrm{LN}_{-} \mathrm{SIZE}_{i, t}+\beta_{15}{\mathrm{DEP} \_S I Z E_{i, t}}+\beta_{16} \mathrm{LTD}_{-} \mathrm{SIZE}_{i, t}+ \\
& \beta_{17} \mathrm{RM}_{-} \mathrm{SEC}_{i, t}+\beta_{18} \mathrm{RM}_{-} \mathrm{LOAN}_{i, t}+\beta_{19} \mathrm{RM}_{2} \mathrm{DEP}{ }_{i, t}+\beta_{20} \mathrm{RM}_{-} \mathrm{LTD}_{i, t}+ \\
& \beta_{21} \mathrm{LN}_{-} \mathrm{CAP}{ }_{i, t}+\beta_{22} \mathrm{LN}_{-} \mathrm{AUD}_{i, t}+\varepsilon_{i, t}
\end{aligned}
$$

\begin{tabular}{|c|c|}
\hline SEC_SIZE & $\begin{array}{l}=\text { DIF_SEC times a dichotomous variable for the sample firm's size (coded ' } 1 \text { ' if the sample } \\
\text { firm's total assets is less than the sample median and '0' otherwise), }\end{array}$ \\
\hline LN_SIZE & $\begin{array}{l}=\text { DIF_LOAN times a dichotomous variable for the sample firm's size (coded ' } 1 \text { ' if the sample } \\
\text { firm's total assets is less than the sample median and ' } 0 \text { ' otherwise), }\end{array}$ \\
\hline DEP_SIZE & $\begin{array}{l}=\text { DIF_DEP times a dichotomous variable for the sample firm's size (coded ' } 1 \text { ' if the sample } \\
\text { firm's total assets is less than the sample median and ' } 0 \text { ' otherwise), }\end{array}$ \\
\hline LTD_SIZE & $\begin{array}{l}=\text { DIF_LTD times a dichotomous variable for the sample firm's size (coded ' } 1 \text { ' if the sample } \\
\text { firm's total assets is less than the sample median and '0' otherwise), }\end{array}$ \\
\hline $\mathrm{RM}$ & $=$ the absolute value of DIF_SEC divided by the historical cost of investment securities, \\
\hline RM_LOAN & $=$ the absolute value of DIF_LOAN divided by the historical cost of net loans, \\
\hline RM_DEP & $=$ the absolute value of DIF_DEP divided by the historical cost of deposits, \\
\hline RM_LTD & $=$ the absolute value of DIF_LTD divided by the historical cost of long-term debt, \\
\hline LN_CAP & $\begin{array}{l}=\text { DIF_LOAN times a dichotomous variable for the sample firm's total capital ratio (coded ' } 1 \text { ' } \\
\text { if the sample firm's total capital ratio is less than the sample median and ' } 0 \text { ' otherwise), and }\end{array}$ \\
\hline LN_A & $\begin{array}{l}=\text { DIF_LOAN times a dichotomous variable for the sample firm's auditor (coded ' } 1 \text { ' if the } \\
\text { sample firm's auditor is not a Big- } 6 \text { auditor and ' } 0 \text { ' otherwise). }\end{array}$ \\
\hline
\end{tabular}

where previously defined variables and model terms are as before:

lam, 1996)]. CON_TRAD is expected to be positive if the expected fee income from acting as an intermediary for customers in transacting with these instruments exceeds the risk taken by banks which use these instruments for speculative purposes.

17 Since the fair values of non-financial instruments are not a required disclosure, the inclusion of this variable implicitly assumes that their aggregate fair value is a cross-sectional multiple of their historical cost.

18 The core deposit intangible represents the benefits a bank receives from having long-standing relationships with its customers. Specifically, a bank pays relatively favorable rates for the use of these depositors' funds compared to other sources of financing. Since these benefits are not recognized on the balance sheet, this proxy is included as a control variable in the statistical model. This proxy is consistent with one employed by Barth et al. (1996).

19 Prior research has also hypothesized that other significant, unrecognized intangible assets exists for many banks. As discussed in Eccher et al. (1996), examples of these intangibles include the ability to evaluate credit risk, loan servicing rights, and control over operating costs. If these unrecorded intangible assets are significant, then a positively significant intercept term is expected in the regression results. 


\section{Journal Of Business And Economics Research}

\section{Volume 1, Number 4}

Based on the reasons provided in section three, no predictions are made about the expected directional relationship between the variables with the 'SIZE' suffix and the market value of firm equity. With respect to the variables with the 'RM' prefix [i.e., Relative Magnitude, as shown in equation (1) above], if market participants believe that large relative differences between the fair value and the historical cost measures enhance the relevance of the fair value disclosures, then a positive (negative) sign is predicted for these variables that relate to assets (liabilities). However, if the market discounts large relative differences, then a negative (positive) association is expected for these variables that relate to assets (liabilities). Since firm financial health and audit quality are hypothesized to impact the reliability of the fair value disclosures for net loans, LN_CAP and LN_AUD are predicted to be negatively related to the market value of firm equity.

A pooled estimation of model (5) is employed to test the impact of the hypothesized factors on the valuerelevance of the SFAS No. 107 fair value disclosures. All of the independent variables in model (5) are measured as of the balance sheet date. The dependent variable, MVE, is calculated by multiplying firm stock price for common equity by the number of common shares outstanding. It is measured as of April 10th following the respective calendar year-end date to ensure that the SFAS No. 107 disclosures are in the public domain. ${ }^{20}$ Each variable that is measured in dollars is deflated by the sample firm's number of shares of stock outstanding at year-end.

The effects of economy-wide or industry-specific events that occur between the balance sheet date and measurement date of the market value of firm equity are mitigated since the analysis is focused solely on the banking industry. Also, the relatively large sample size analyzed diminishes the impact of firm-specific events during the same period.

\section{Description Of The Sample}

\subsection{Sample Selection And Data Collection}

The sample for this study consists of 867 firm years for calendar year-end banks and bank holding companies listed on both the CRSP and Compustat Bank tapes over the two-year period of 1996 and 1997. Table 1 provides a summary of the sample composition for this research. The financial statements and related footnotes for sample firms were obtained from each firm's Form 10-K filed on the SEC's electronic filing database (i.e., Edgar). Stock price data were gathered from the CRSP tapes. SFAS No. 107 disclosures were collected manually from the financial statements. All other variables were gathered from the financial statements and the Compustat Bank tapes.

\subsection{Summary Statistics}

Summary statistics of the historical cost and fair value measurements of relevant balance sheet items are shown in Table 2. The results indicate that net loans represent the largest asset for the sample firms and together with investment securities comprise on average approximately seventy-one percent of total assets. Additionally, deposits represent the largest liability for the sample firms and together with long-term debt comprise on average approximately seventy-six percent of total liabilities. Fair value measurements exceeded the related historical cost measurements on average for each financial instrument during the sample period.

\subsection{Descriptive Statistics}

Table 3 provides descriptive statistics for the data used to estimate equation (5). The descriptive statistics show the size diversity of sample firms. This diversity is one of the primary contributions of the analysis, as the three studies previously examining SFAS No. 107 fair value disclosures for the banking industry focused primarily on large banks.

\footnotetext{
20 The SEC requires its registrants to file Form 10-K, which includes audited financial statements and footnotes, within 90 days of year-end. For comparison purposes, the studies by Nelson (1996), Barth et al. (1996), and Eccher et al. (1996) measured market value of equity as of March 31st, April 30th, and December 31st, respectively.
} 


\section{Journal Of Business And Economics Research}

\section{Volume 1, Number 4}

The average (median) market value of equity of sample firms amounts to approximately $\$ 1.8$ billion $(\$ 168$ million). Also, the average (median) ratio of market value of equity to the historical cost of net assets is 2.57 (1.97), indicating that the market has assigned a significant premium to these banks over the historical cost of net assets.

The mean unrealized gain for the sum of investment securities and net loans amounted to $\$ 114.988$ million, or $16.81 \%$ of the mean historical cost of net assets. Additionally, the mean unrealized loss for the sum of deposits and long-term debt amounted to $\$ 14.816$ million, or $2.17 \%$ of the mean historical cost of net assets.

Based on the variables with the 'RM' prefix, the average difference between the fair value and historical cost measurements exceeds one percent for investment securities, net loans, and long-term debt. Not surprisingly, the smallest difference between the fair value and historical cost measurement is for deposits, most likely due to the requirement of SFAS No. 107 that the fair value of deposits with no stated maturity be reported at the amount payable at demand (i.e., the historical cost) [FASB, 1991, para. 12].

Table 3 indicates that the average fair value of derivative instruments held for asset-liability purposes amounted to $\$ 7.865$ million, an average net receivable position. Also, non-performing loans represented less than one percent of total assets, on average. Finally, $185(21 \%)$ of the sample of 867 firm years, were not audited by a Big-Six auditor.

\section{Results}

Table 4 provides the pooled regression results for the estimating equation. The sample size reported in the table represents the number of observations for which there are no missing data items. As shown in Table 4, the variables measuring the difference between the fair value and historical cost for SFAS No. 107 financial instruments were statistically significant for investment securities (DIF_SEC), net loans (DIF_LOAN), and long-term debt (DIF_LTD), indicating that the fair value disclosures for these financial instruments are value-relevant beyond historical cost measures in explaining firm value. As predicted, the signs of the coefficients are positive for both investment securities and net loans. A positive sign, which is opposite the prediction, was attained for long-term debt. However, the positive sign for long-term debt is consistent with findings by Nelson (1996) and Eccher et al. (1996) in selected specifications. This anomalous sign is discussed in more detail below.

Also, consistent with findings from prior research, the variable measuring the difference between the fair value and historical cost for deposits (DIF_DEP) was not statistically significant. The lack of significance for this variable is likely attributable to the requirement in SFAS No. 107 that the fair value of deposits with no stated maturity be reported as the amount payable on demand at the reporting date. Further, as shown in Table 3, the average difference between the fair value and historical cost of deposits is the smallest among the SFAS No. 107 financial instruments examined in this study.

The variable measuring the fair value of derivative financial instruments used for asset-liability management (FV_ALM) was positively significant, as predicted. This finding indicates the fair value disclosures for these instruments, as required by SFAS No. 119, represent an improvement over the previously required disclosures in SFAS No. 107. The studies by Nelson (1996), Barth et al. (1996) and Eccher et al. (1996), which were all conducted during sample periods prior to the enactment of SFAS No. 119, consistently found this variable to be not statistically significant in explaining firm value.

Additional analysis of the regression results from Table 4 indicate that the intercept term is positive and statistically significant. This finding is consistent with the theory that significant, unrecognized intangible assets exist for many banks, such as the deposit base intangible often valued in mergers and acquisitions. Also, consistent with expectations, the variable measuring the historical cost of net assets (HC_NA) was positively significant, indicating that historical cost disclosures still play an instrumental role in explaining firm value.

Among the control variables included in the model, the contractual amount of off-balance sheet credit in- 


\section{Journal Of Business And Economics Research}

\section{Volume 1, Number 4}

struments (CON_OFFB), the contractual amount of trading derivatives (CON_TRAD), the historical cost of net assets other than the SFAS No. 107 financial instruments accounted for separately in the model (NON_107), the proxy for the core deposit intangible asset (CORE_DEP), and non-performing loans (NPL) were all statistically significant and with the expected sign, when predicted. Interestingly, the significance of NPL indicates that market participants do not believe that the fair value disclosure for net loans fully captures their related credit risk. Also, the negative sign for the contractual amount of trading derivatives indicates that the market penalizes firms which engage in transactions involving derivatives used for trading purposes. The most likely inference from this finding is that the market believes that firms use these financial instruments for speculation purposes, since many banks offset their positions when engaging in transactions with these instruments as a dealer.

With respect to the factors hypothesized to impact the relevance and/or reliability of the SFAS No. 107 financial instruments, the size of the bank was found to play a significant role. Specifically, of the four variables that interact the dummy variable coded for firm size and the financial instrument variables, LN_SIZE and LTD_SIZE were found to be negative and statistically significant from zero at the 0.01 level. Importantly, this finding indicates that market participants discount the fair value disclosures for loans and long-term debt for relatively smaller firms. Further, the negative sign provides evidence as to which of the competing theories dominates in explaining the significant role of firm size on the value-relevance of the fair value disclosures. Specifically, one can infer that market participants believe that the fair value disclosures for larger firms are more value-relevant, presumably due to the ability of larger firms to develop more accurate measures of fair value.

As noted in Table 4, SEC_SIZE and DEP_SIZE were not found to be statistically significant. A plausible explanation for this occurrence for SEC_SIZE is the relatively ease of determining fair values for actively-traded debt securities, regardless of whether the bank holding these assets are large or small. Also, the lack of significance for DEP_SIZE is not surprising due to the lack of significance of DIF_DEP.

Finally, one last interesting result for the size interaction variables relates to the unexpected positive sign for DIF_LTD. Specifically, the sum of the coefficients for DIF_LTD and LTD_SIZE is negative, indicating that the difference between the fair value and historical cost of long-term debt is negatively related to the market value of equity for relatively small firms.

The second factor hypothesized to impact the value-relevance of SFAS No. 107 disclosures is the relative magnitude of the difference between the fair value and historical cost of these disclosures. The results from Table 4 indicate that RM_SEC and RM_LTD are statistically different from zero at the 0.01 level. The signs of the coefficients for these variables are the opposite from the sign predictions for the related fair value disclosure variables (i.e., DIF_SEC and DIF_LTD), indicating that market participants discount the fair value disclosures in instances where the difference between the fair value estimates and historical cost measures are relatively large.

Finally, both LN_CAP and LN_AUD are negative and significant at the 0.05 level. This finding indicates that market participants, being aware of the more subjective nature of establishing a fair value estimate for net loans compared to the other financial instrument variables, sought other information in order to evaluate the reliability of this fair value estimate. These findings indicate that financial health of the bank and the quality of the financial statement audit impact the reliability of this disclosure. Specifically, the negative sign reveals that market participants discount the fair value disclosure of loans if the bank is relatively less healthy and/or it is not audited by a Big6 firm.

\subsection{Sensitivity Analysis}

The presence of multicollinearity among independent variables could impact the explanatory power of the regression variables. One measure for evaluating the effects of collinearity among independent variables is calculating variance inflation factors. A suggested guideline for this measure is if the variance inflation factor related to a regression coefficient exceeds ten, then multicollinearity may be a concern. The variance inflation factors (i.e., 


\section{Journal Of Business And Economics Research}

\section{Volume 1, Number 4}

the VIF's reported in Table 4) related to each regression coefficient were all less than ten, mitigating concerns about the effects of multicollinearity.

Additionally, correlations between the independent variables were examined. It was noted that relatively strong correlations exist between CON_OFFB, CON_ALM, and CON_TRAD. As a specification check, CON_ALM and CON_TRAD were eliminated from the estimation equation. The regression results from this specification were similar to those reported in Table 4 (results not presented).

Finally, equation (5) was estimated after controlling for interest rate sensitive assets and interest rate sensitive liabilities, as done by Barth et al. (1996). Data limitations for these additional variables reduced the sample for this specification to 720 firms. In this specification, the variable which controls for interest rate sensitive liabilities (INTSENLI) was significant at the 0.05 level. Additionally, the findings related to the SFAS No. 107 financial instruments and the hypothesized factors are similar to those reported in Table 4 (results not presented).

\section{Summary And Conclusions}

This study examines the impact of hypothesized factors on the value-relevance of SFAS No. 107 fair value disclosures. These factors include firm size, the relative magnitude of the difference between the fair value and the historical cost measurements for each financial instrument, firm financial condition, and the quality of a firm's financial statement audit. Using a sample of 867 calendar year-end banks during the period of 1996 and 1997 , a pooled valuation model is used to test the impact of hypothesized factors on the value-relevance of SFAS No. 107 fair value disclosures. The estimating equation controlled for variables which prior research has shown to impact the market value of banks.

Results indicate that the SFAS No. 107 fair value disclosures for investment securities, net loans, and longterm debt are value-relevant in explaining the market value of common equity for the sample banks. With respect to the hypothesized factors, firm size had a statistically significant impact on the value-relevance of the disclosures for net loans and long-term debt. Additionally, the relative magnitude of the difference between the fair value and historical cost had a statistically significant effect on the value-relevance of the disclosure for investment securities and long-term debt. Finally, firm financial condition and the quality of a firm's audit were found to have a statistically significant impact on the fair value disclosure for net loans. Taken together, these findings suggest that market participants do not respond to the SFAS No. 107 fair value disclosures at their face value alone or without considering their context. Specifically, they look to other factors which may impact the relevance and or reliability of these disclosures.

The implications of the findings for this study are useful for both accounting standard-setters and preparers of financial statements. The results are descriptive of the behavior of users of financial statements with respect to these fair value disclosures.

Finding firm size as a significant factor impacting the value-relevance of SFAS No. 107 fair value disclosures implies that financial accounting standard-setters may need to re-evaluate whether different disclosure standards should be required for relatively large and small firms. Alternatively, standard-setters may need to consider whether prescribed fair value estimation techniques should be employed by all firms to mitigate differences in the value-relevance of their disclosures.

The conclusion that the relative magnitude of the difference between the fair value disclosure and historical cost was statistically significant for investment securities and long-term debt provides descriptive evidence about the behavior of market participants. Specifically, the results imply that when the differences between the fair value disclosure and historical cost are relatively large for these financial instruments, market participants discounted the fair value disclosure.

The result that firm financial condition was a statistically significant factor impacting the value-relevance of 


\section{Journal Of Business And Economics Research}

\section{Volume 1, Number 4}

the fair value disclosure for net loans provides descriptive evidence that market participants, being aware of potentially opportunistic behavior by management, discount this fair value disclosure for less-healthy firms. Finally, the finding that a proxy for the quality of a firm's audit was a statistically significant factor impacting the valuerelevance of the fair value disclosure for net loans has the implication of providing incentives for financial statement preparers to hire high-quality auditors. Specifically, this study found that the fair value disclosure for net loans were discounted by market participants if the sample firm did not receive a high-quality audit. The proxy for audit quality employed in this study was based on whether or not the sample firm employed a Big-Six auditor.

The debate about the usefulness of historical cost measurements being used as the primary basis in preparing financial statements is ongoing. Proponents of this system argue that it provides relevant and reliable measurements. However, proponents of a fair value accounting system contend that fair value measurements provide more relevant information in assessing the future cash flow prospects of a firm. With its recent movement requiring increased fair value recognition and disclosure of fair values, the FASB appears to see the merits of fair value information being made available to financial statement users.

The objective of this study was to provide descriptive information to preparers and standard-setters about the behavior of financial statement users relative to the SFAS No. 107 fair value disclosures for the purpose of improving the financial reporting system. In conclusion, the results of this study indicate that market participants do infact use fair value disclosures in valuing firm equity. Additionally, hypothesized factors are shown to impact the relevance and/or reliability of these disclosures.

\section{References}

1. American Institute of Certified Public Accountants. 1992. Auditing Accounting Estimates Auditing Interpretations of Section 342.

2. Barth, M., W. Beaver, and W. Landsman. 1996. Value-relevance of banks' fair value disclosures under SFAS No. 107. The Accounting Review 71 (October): 513-537.

3. DeAngelo, L. 1981. Auditor size and audit quality. Journal of Accounting and Economics: $183-199$.

4. Eccher, A., K. Ramesh, and S. R. Thiagarajan. 1996. Fair value disclosures by bank holding companies. Journal of Accounting and Economics (Supplement): 79-117.

5. Financial Accounting Standards Board (FASB). 1980. Qualitative Characteristics of Accounting Information. Statement of Financial Accounting Concepts No. 2. Stamford, CT.

6. Financial Accounting Standards Board (FASB). 1991. Disclosures about Fair Value of Financial Instruments. Statement of Financial Accounting Standard No. 107. Norwalk, CT.

7. Financial Accounting Standards Board (FASB). 1994. Disclosure about Derivative Financial Instruments and Fair Value of Financial Instruments. Statement of Financial Accounting Standard No. 119. Norwalk, CT.

8. Nelson, K. 1996. Fair value accounting for commercial banks: An empirical analysis of SFAS No. 107. The Accounting Review 71 (April): 161-182.

9. Petroni, K. and J. Wahlen. 1995. Fair values of equity and debt securities and share prices of propertyliability insurance companies. Journal of Risk and Insurance. (62): 719-737.

10. Simko, P. 1999. Financial instrument fair values and nonfinancial firms. Journal of Accounting, Auditing \& Finance. (14): 247-274.

11. Venkatachalam, M. 1996. Value-relevance of banks' derivatives disclosures. Journal of Accounting and Economics (22): 327-355. 
Table 1 - Sample Selection Procedures

$\underline{1996}$

1997

$\underline{\text { Pooled }}$

Total Number of Banks and Bank

Holding Companies Listed on Both

Bank Compustat and CRSP

628

1,241

Less:

Firms with a fiscal year-end other

than the calendar-year

Firms not incorporated in the United

States

Firms for whom financial statement data was not obtained ${ }^{\mathrm{a}}$

$\underline{(44)}$

Sample

426

441

867

Table 2 - Summary Statistics (amounts measured in thousands)

Historical Cost Measurements

\begin{tabular}{|c|c|c|c|c|c|c|}
\hline Balance Sheet Item & $\mathrm{N}$ & Mean & $\begin{array}{c}\text { First } \\
\text { Quartile }\end{array}$ & Median & $\begin{array}{c}\text { Third } \\
\text { Quartile }\end{array}$ & $\begin{array}{l}\text { Standard } \\
\text { Deviation }\end{array}$ \\
\hline Investment Securities & 867 & $1,474,541$ & 82,162 & 221,449 & 760,640 & $4,355,798$ \\
\hline Net Loans & 867 & $5,105,884$ & 247,424 & 598,421 & $1,849,202$ & $17,740,234$ \\
\hline Total Assets & 867 & $9,269,599$ & 384,034 & 947,282 & $3,069,165$ & $33,928,183$ \\
\hline Deposits & 867 & $5,784,789$ & 313,357 & 736,642 & $2,137,834$ & $19,519,509$ \\
\hline Long-term Debt & 867 & 743,207 & 2,241 & 25,234 & 150,000 & $2,789,970$ \\
\hline Total Liabilities & 867 & $8,566,257$ & 346,715 & 855,555 & $2,857,309$ & $31,583,150$ \\
\hline
\end{tabular}

Fair Value Measurements

\begin{tabular}{lccrrrr} 
Balance Sheet Item & \multirow{2}{*}{ Mean } & $\begin{array}{c}\text { First } \\
\text { Quartile }\end{array}$ & Median & \multicolumn{1}{c}{$\begin{array}{c}\text { Third } \\
\text { Quartile }\end{array}$} & $\begin{array}{c}\text { Standard } \\
\text { Deviation }\end{array}$ \\
\hline Investment Securities & 867 & $1,495,580$ & 82,654 & 222,512 & 769,504 & $4,408,560$ \\
Net Loans & 867 & $5,199,833$ & 248,602 & 604,850 & $1,920,419$ & $18,115,186$ \\
Deposits & 867 & $5,789,692$ & 313,641 & 739,711 & $2,144,365$ & $19,525,018$ \\
Long-term Debt & 867 & 753,120 & 2,239 & 25,842 & 154,447 & $2,828,898$ \\
\hline
\end{tabular}

a For these firms, the 10-K filing was either not included on the SEC's Edgar database, the Edgar filing was not in reader-friendly form, or the filing did not include the financial statements and related footnotes. In such instances, the firms were contacted on at least two occasions and were requested to mail respective copies of form $10-\mathrm{K}$ or the Annual Report. The firms included here are those from whom no response was received. 
Journal Of Business And Economics Research Volume 1, Number 4 
Table 3 - Descriptive Statistics

\begin{tabular}{|c|c|c|c|c|c|c|c|c|}
\hline$\underline{\text { Data Item }}$ & $\mathrm{N}$ & Mean & Minimum & Median & Maximum & $\begin{array}{r}\text { Standard } \\
\text { Deviation }\end{array}$ & $\mathrm{N}>0$ & $\mathrm{~N}=0$ \\
\hline MVE & 851 & $1,758,274$ & 4,713 & 167,761 & $74,829,541$ & $6,100,014$ & 851 & 0 \\
\hline HC_NA & 867 & 684,024 & 3,381 & 85,254 & $22,108,000$ & $2,360,217$ & 867 & 0 \\
\hline DIF_SEC & 867 & 21,039 & $-245,000$ & 951 & $3,311,979$ & 159,024 & 666 & 4 \\
\hline DIF_LOAN & 867 & 93,949 & $-555,000$ & 4,381 & $6,100,000$ & 467,007 & 716 & 9 \\
\hline DIF_DEP & 867 & 4,903 & $-1,636,089$ & 791 & 442,000 & 78,927 & 685 & 11 \\
\hline DIF_LTD & 867 & 9,913 & $-151,766$ & 0 & 700,000 & 53,010 & 343 & 303 \\
\hline FV_ALM & 867 & 7,865 & $-462,000$ & 0 & $2,100,000$ & 96,908 & 147 & 626 \\
\hline CON_OFFB & 867 & $5,394,583$ & 0 & 105,576 & $307,200,000$ & $27,008,903$ & 865 & 2 \\
\hline CON_ALM & 867 & $3,339,967$ & 0 & 0 & $335,300,000$ & $23,693,160$ & 281 & 586 \\
\hline CON_TRAD & 867 & $46,226,309$ & 0 & 0 & $7,506,300,000$ & $439,060,000$ & 82 & 785 \\
\hline NON107 & 867 & 631,595 & $-15,370,000$ & 33,108 & $39,983,000$ & $3,770,774$ & 687 & 0 \\
\hline CORE_DEP & 867 & $2,345,364$ & $-45,940,000$ & 344,684 & $76,520,000$ & $8,868,364$ & 861 & 0 \\
\hline NPL & 866 & 57,438 & 0 & 4,960 & $4,531,000$ & 261,691 & 861 & 5 \\
\hline ASSETS & 867 & $9,269,599$ & 57,529 & 947,282 & $365,520,000$ & $33,928,183$ & 867 & 0 \\
\hline RM_SEC & 867 & .012068 & 0 & .006531 & .393472 & .025894 & 863 & 4 \\
\hline RM_LOAN & 867 & .014415 & 0 & .010840 & .187062 & .015951 & 858 & 9 \\
\hline RM_DEP & 867 & .003377 & 0 & .001809 & .085516 & .006005 & 856 & 11 \\
\hline RM_LTD & 867 & .015276 & 0 & .001671 & .530047 & .039831 & 564 & 303 \\
\hline CAPRATIO & 867 & 15.366 & 6.38 & 14.12 & 47.80 & 5.021 & 867 & 0 \\
\hline AUD_QUAL & 867 & .213 & 0 & 0 & 1 & .410 & 185 & 682 \\
\hline
\end{tabular}

where dollar amounts are measured in thousands and data items are defined as follows:

MVE = market value of common equity, measured as of April 10, 1997 for the 1996 sample year and April 10, 1998 for the 1997 sample year.

HC_NA $\quad=$ the historical cost of net assets.

= the difference between the fair value and the historical cost of investment securities.

DIF_LOAN $\quad=$ the difference between the fair value and historical cost of net loans.

$\begin{array}{ll}\text { I } & \text { the difference between the fair value and historical cost of deposits. } \\ \text { DIF_LTD } & =\text { the difference between the fair value and historical cost of long-term debt. }\end{array}$

FV_ALM $\quad$ the fair value of derivative financial instruments used for asset-liability management purposes.

CON_OFFB $\quad=$ the contractual amount of credit-related off-balance sheet financial instruments.

CON_ALM $\quad$ = the contractual (notional) amount of derivatives used for asset-liability management purposes.

CON_TRAD $\quad=$ the contractual (notional) amount of derivatives used for trading.

CON_TRAD $\quad=$ the contor

CORE_DEP $\quad=$ a proxy for the core deposit intangible, measured as total domestic deposits less total time deposits.

$\begin{array}{ll}\text { NPL } & =\text { a proxy for the core deposit intangible, measured as total domestic deposits less total time deposits. } \\ \text { = non-performing loans, measured as the sum of loans placed on non-accrual status, loans ninety days or more past due and still accruing interest, and restructured loans. }\end{array}$

ASSETS

ASSETS

RM_SEC $\quad=$ the absolute value of DIF_SEC divided by the historical cost of investment securities.

RM_LOAN the absolute value of DIF_LOAN divided by the historical cost of net loans.

$\begin{array}{ll}\text { RM_DEP } & \text { the absolute value of DIF_DEP divided by the historical cost of deposits. } \\ \text { RM_LTD } & =\text { the absolute value of DIF_LTD divided by the historical cost of long-term debt. }\end{array}$

CAPRATIO $\quad$ the total capital ratio.

AUD_QUAL $\quad=$ a proxy for audit quality, coded ' 1 ' if the sample firm's auditor is not a Big-6 auditor and ' 0 ' otherwise 
Table 4 - Regression Estimates $(n=850)$



\begin{tabular}{|c|c|c|c|c|}
\hline Variable & Predicted Sign & Coefficient & t-statistic & VIF \\
\hline Intercept & $?$ & 7.220 & $7.263 * * *$ & 0.000 \\
\hline HC_NA & + & 1.224 & $15.826 * * *$ & 4.560 \\
\hline DIF_SEC & + & 3.954 & $6.843 * * *$ & 2.171 \\
\hline DIF_LOAN & + & 2.398 & $4.259 * * *$ & 9.383 \\
\hline DIF_DEP & - & -0.464 & -0.836 & 1.778 \\
\hline DIF_LTD & - & 6.314 & $5.159 * * *$ & 1.863 \\
\hline FV_ALM & + & 5.763 & $4.512 * * *$ & 1.576 \\
\hline CON_OFFB & $+/-$ & 0.075 & $9.691 * * *$ & 2.419 \\
\hline CON_ALM & $+/-$ & 0.010 & 1.109 & 5.824 \\
\hline CON_TRAD & $+/-$ & -0.001 & $-2.788 * * *$ & 3.929 \\
\hline NON107 & $+/-$ & -0.037 & $-1.955 *$ & 1.919 \\
\hline CORE_DEP & + & 0.059 & $4.362 * * *$ & 3.406 \\
\hline NPL & - & -1.113 & $-4.304 * * *$ & 1.326 \\
\hline SEC_SIZE & $+/-$ & 0.970 & 0.786 & 1.220 \\
\hline LN_SIZE & $+/-$ & -1.793 & $-3.881 * * *$ & 1.830 \\
\hline DEP_SIZE & $+/-$ & -0.376 & -0.423 & 1.675 \\
\hline LTD_SIZE & $+/-$ & -8.219 & $-3.164 * * *$ & 1.300 \\
\hline RM_SEC & $+/-$ & -61.177 & $-2.862 * * *$ & 1.940 \\
\hline RM_LOAN & $+/-$ & -49.221 & -1.118 & 2.989 \\
\hline RM_DEP & $+/-$ & -96.557 & -1.332 & 1.239 \\
\hline RM_LTD & $+/-$ & 30.395 & $2.964 * * *$ & 1.085 \\
\hline LN_CAP & - & -0.793 & $-1.720 * *$ & 5.570 \\
\hline LN_AUD & - & -1.130 & $-2.144 * *$ & 1.667 \\
\hline Adj $\mathrm{R}^{2}$ & & .79 & & \\
\hline \multicolumn{5}{|c|}{ Variables are as defined in Table 3. Additional variable definitions are as follows: } \\
\hline SEC_SIZE & \multicolumn{4}{|c|}{$\begin{array}{l}=\text { DIF_SEC multiplied by a dichotomous variable which is coded ' } 1 \text { ' if the sample firm's total assets is less than the } \\
\text { sample median and ' } 0 \text { ' otherwise. }\end{array}$} \\
\hline LN_SIZE & \multicolumn{4}{|c|}{$\begin{array}{l}=\text { DIF_LOAN multiplied by a dichotomous variable which is coded ' } 1 \text { ' if the sample firm's total assets is less than the } \\
\text { sample median and ' } 0 \text { ' otherwise. }\end{array}$} \\
\hline DEP_SIZE & \multicolumn{4}{|c|}{$\begin{array}{l}=\text { DIF_DEP multiplied by a dichotomous variable which is coded ' } 1 \text { ' if the sample firm's total assets is less than the } \\
\text { sample median and ' } 0 \text { ' otherwise. }\end{array}$} \\
\hline LTD_SIZE & \multicolumn{4}{|c|}{$\begin{array}{l}=\text { DIF_LTD multiplied by a dichotomous variable which is coded ' } 1 \text { ' if the sample firm's total assets is less than the } \\
\text { sample median and ' } 0 \text { ' otherwise. }\end{array}$} \\
\hline LN_CAP & \multicolumn{4}{|c|}{$\begin{array}{l}=\text { DIF_LOAN multiplied by a dichotomous variable which is coded ' } 1 \text { ' if the sample firm's total capital ratio is less than } \\
\text { the sample median and ' } 0 \text { ' otherwise. }\end{array}$} \\
\hline LN_AUD & \multicolumn{4}{|c|}{$\begin{array}{l}=\text { DIF_LOAN multiplied by a dichotomous variable which is coded ' } 1 \text { ' if the sample firm's auditor is not a Big- } 6 \text { auditor } \\
\text { and ' } 0 \text { ' otherwise. }\end{array}$} \\
\hline \multicolumn{5}{|c|}{ All variables other than RM_SEC, RM_LOAN, RM_DEP, and RM_DEP are deflated by year-end shares outstanding. } \\
\hline \multicolumn{5}{|c|}{ One-tailed tests are used when the coefficient sign is as predicted. Two-tailed tests are employed otherwise. } \\
\hline \multicolumn{5}{|c|}{$\begin{aligned} & * * * \text { Statistical significance at } \mathrm{p}<0.01 \\
& * * \text { Statistical significance at } \mathrm{p}<0.05 \\
& * \text { Statistical significance at } \mathrm{p}<0.10\end{aligned}$} \\
\hline
\end{tabular}

